\title{
Note on Glycaspis brimblecombei Moore (Hemiptera Psyllidae): A new pest of Eucalyptus in Greece"
}

\author{
Antonios E. Tsagkarakis ${ }^{1 \#}$, Argyro P. Kalaitzaki ${ }^{2}$, Georgios N. Balotis ${ }^{3}$ \\ ${ }^{1}$ Laboratory of Agricultural Zoology and Entomology, Agricultural University of Athens, Athens, Greece; \\ \#Corresponding Author: atsagarakis@aua.gr \\ ${ }^{2}$ Hellenic Ministry of Rural Development and Food, Chania, Greece \\ ${ }^{3}$ Institute of Agronomical Sciences, Hellenic Ministry of Rural Development and Food, Kifissia, Greece
}

Received 27 November 2013; revised 8 January 2014; accepted 15 January 2014

Copyright (C 2014 Antonios E. Tsagkarakis et al. This is an open access article distributed under the Creative Commons Attribution License, which permits unrestricted use, distribution, and reproduction in any medium, provided the original work is properly cited. In accordance of the Creative Commons Attribution License all Copyrights (C) 2014 are reserved for SCIRP and the owner of the intellectual property Antonios E. Tsagkarakis et al. All Copyright (C) 2014 are guarded by law and by SCIRP as a guardian.

\section{ABSTRACT}

\section{Leaves of eucalyptus infested by Glycaspis brim- blecombei Moore were found on river red gum (E. camaldulensis) and blue gum (E. globulus) trees in Attiki and Chania region, Greece. The psyllid is recorded for the first time in Greece. Brief information about this psyllid is provided.}

\section{KEYWORDS}

\section{Red Gum Lerp Psyllid; First Record; Eucalyptus globulus; E. camaldulensis}

The red gum lerp psyllid, Glycaspis brimblecombei, is one of the 137 species of the genus Glycaspis Taylor, which is associated with Eucalyptus spp. [1]. Having origin from Australia [2], it uses several eucalyptus species as hosts, with a preference on E. camaldulensis and E. tereticornis [3-6]. In the late 1990's and during 2000's, it was introduced into a number of countries in the Americas: USA in 1998 [6], Mexico in 2000 [6], Chile in 2002 [7], Brazil in 2003 [8], Argentina [9], Ecuador [10], Venezuela [11], Peru [12]. Later on it was detected in Europe: The Iberian Peninsula [13-15] and Italy [16].

The exact time of arrival of $G$. brimblecombei in Greece is not known. This species, as mentioned above, is present in Italy [16] and probably was accidentally brought in from the above mentioned country. It was added to the EPPO Alert List in 2002, but deleted in 2006 (the alert had been given for 3 years and no further action was taken) [16].

*During publishing of the present manuscript, an article on the presence of Glycaspis brimblecombei was published by Bella and Rapisarda, 2013.
Eucalyptus leaves infested by G. brimblecombei, with crystal-white coverings on them (Plate 1), were collected from Attiki, Central Greece (Pefki, 01.06.13; Amaroussion, 21.06.13; Plaka, 29.06.13) and Chania, Crete (Chryssopigi, 01.07.13). The infested trees, which belong to $E$. camaldulensis and E. globulus species, were covered with honeydew excretions and were visited by numerous honeybees in order to collect them.

Glycaspis brimblecombei is the only psyllid known to feed on Eucalyptus in Greece. Infestations of G. brimblecombei are most easily recognized by the conical white coverings (lerps) secreted by the nymphs (Plate 2(a)). The psyllid nymphs are reddish bronze with darker wing pads that have bright white spots (Plate 2(b)).

Adults are yellow to green in color and are winged and highly mobile (Plate 3 ). The anterior part of the head of the adults has a pair of curious long projections called genae.

Females lay eggs randomly on the leaves or in clusters of 50 - 75 eggs, usually at an angle or perpendicular to the plant surface. Eggs are about $1 \mathrm{~mm}$ in length, yellow

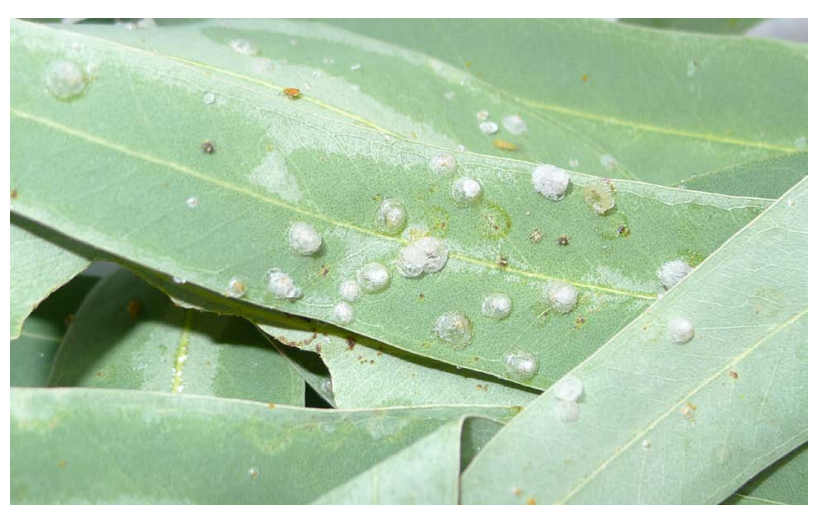

Plate 1. Eucalyptus leaves infested by G. brimblecombei. 


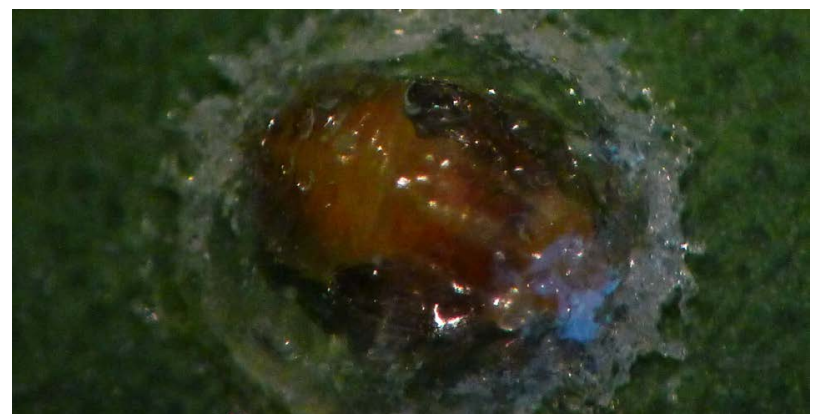

(a)

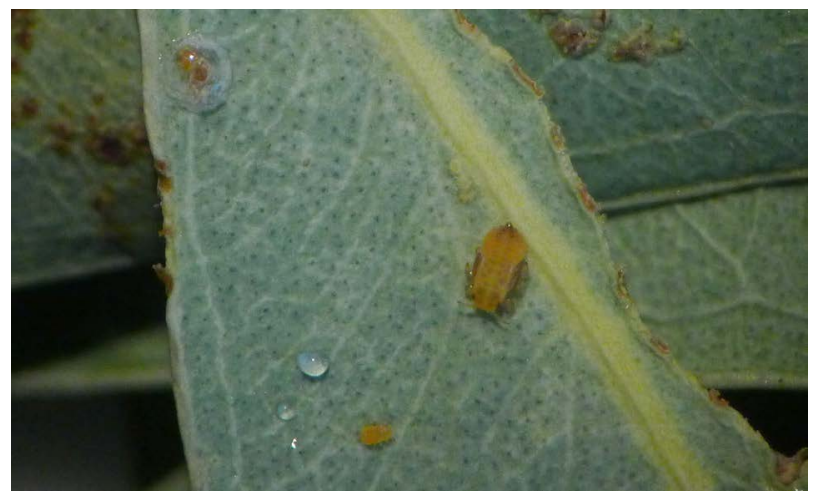

(b)

Plate 2. (a) Crystal-white lerp covering a $4^{\text {th }}$ instar nymph of $G$. brimblecombei; (b) G. brimblecombei nymphs.

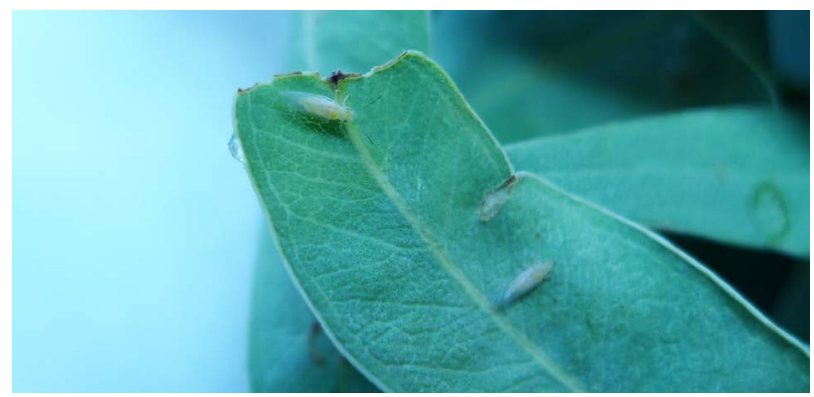

Plate 3. Adult of G. brimblecombei.

or cream coloured (Plate 4). Detailed descriptions of $G$. brimblecombei have been published by Moore [2], Halbert et al. [17] and Olivares et al. [7].

Brennan and Gill [18] refer the host range of G. brimblecombei in Eucalyptus species: E. blakelyi Maiden, E. brassiana Blake, E. bridgesiana Baker, E. camaldulensis Dehnh., E. camphora Baker, E. dealbata Cunn. Ex Schauer, E. mannifera ssp. maculosa Baker, E. nitens Deane \& Maiden, and E. teriticornis Smith, E. diversicolor F. Muell, E. globulus Labill and E. sideroxylon Cunn.

Glycaspis brimblecombei is referred in North America as more damaging than other eucalyptus psyllids, because it can cause defoliation of infested trees, and it has a relatively broad host range among Eucalyptus species [18].

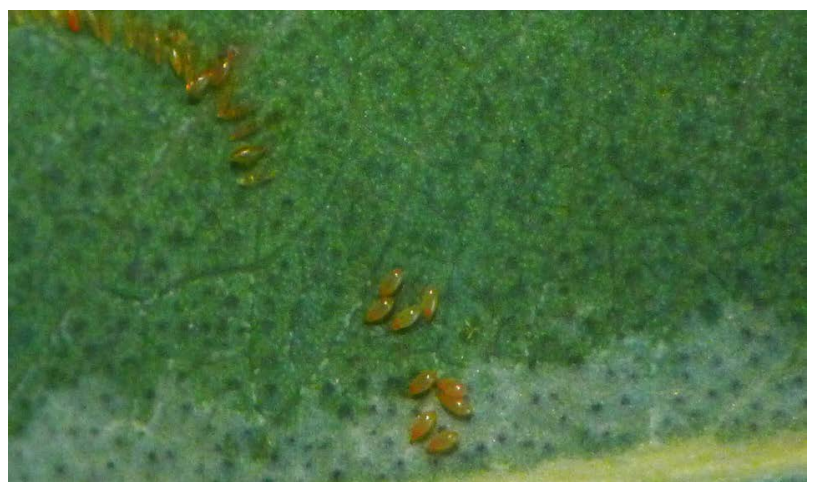

Plate 4. Eggs of G. brimblecombei.

The work on life history and relationships of the red gum lerp psyllid and the survey of its distribution in Greece are continuing, together with research on natural enemies, predators and parasitoids, which will contribute to the control of that pest.

\section{REFERENCES}

[1] Hollis, D. (2004) Australian psylloidea: Jumping plantlice and lerp insects. Australian Government, Department of Environment and Heritage, Canberra.

[2] Moore, K.M. (1964) Observations on some Australian forest insects. 18. Four new species of Glycaspis (Homoptera: Psyllidae) from Queensland. Proceedings of the Linnean Society of New South Wales, 89, 163-166.

[3] Moore, K.M. (1970) Observations on some Australian forest insects. 23. A revision of the genus Glycaspis (Homoptera: Psyllidae) with descriptions of seventy-three new species. Australian Zoologist, 15, 248-341.

[4] Moore, K.M. (1975) The Glycaspis spp. (Homoptera, Psyllidae) associated with Eucalyptus camaldulensis. Proceedings of the Linnean Society of New South Wales, 99, 121-128.

[5] Brennan, E.B., Hrusa, G.F., Weinbaum, S.A. and Levison Jr., W. (2001) Resistance of Eucalyptus species to Glycaspis brimblecombei (Homoptera: Psyllidae) in the San Francisco Bay area. Pan-Pacific Entomologist, 77, 249253.

[6] Paine, T.D., Dreistadt, S.H., Garrison, R.W. and Gill, R.J. (2006) Eucalyptus redgum lerp psyllid. Pest Notes, 7460, 1-4.

http://www.ipm.ucdavis.edu/PDF/PESTNOTES/pneucaly ptusredgumpsyllid.pdf

[7] Olivares, T.S., Burckhardt, D.H. and Cerda, L.A. (2004) Glycaspis brimblecombei Moore, "Psyllido de los eucaliptos rojos” (Hemiptera: Psyllidae: Spondyliaspidinae): Caracteres taxonómicos. Revista Chilena de Entomología, 30, 5-10.

[8] Santana, D.L.Q., Menezes Júnior, A., Silva, H.D, Bellote, A.F.J. and Favaro, R.M.F. (2003) Psilídeo-de-concha (Glycaspis brimblecombei) em eucalipto. Embrapa Florestas, Colombo, Comunicado Técnico, 10, 1-3. 
[9] Bouvet, J.P.R., Harrand, L. and Buckhardt D. (2005) Primera cita de Blastopsylla occidentalis y Glycaspis brimblecombei (Hemiptera: Psyllidae) para la República Argentina. Revista de la Sociedad Entomológica Argentina, 64, 99-102.

[10] Onore, G. and Gara, R.L. (2007) First record of Glycaspis brimblecombei (Hemiptera: Psyllidae) in Ecuador, biological notes and associated fauna. Extended Abstracts of the 4th European Hemiptera Congress, Turin, 10-14 September 2007, 41-42.

[11] Rosales, C.J., Lobosque, O., Carvalho, P., Bermúdez, L. and Acosta, C. (2008) Glycaspis brimblecombei Moore (Hemiptera: Psyllidae) "Red Gum Lerp". Nueva plaga forestal en Venezuela. Entomotropica, 23, 103-104.

[12] Burckhardt, D., Lozada, P.W. and Diaz, B.W. (2008) First record of the red gum lerp psyllid Glycaspis brimblecombei (Hemiptera: Psylloidea) from Peru. Mitteilungen der Schweizerischen Entomologische Gesellschaft, 81, 83-85.

[13] Hurtado, A. and Reina, I. (2008) Primera cita para Europa de Glycaspis brimblecombei Moore (Hemiptera: Psyllidae), una nueva plaga del eucalipto. Boletín Sociedad Entomológica Aragonesa, 43, 447-449.
[14] Prieto-Lillo, E., Rueda, J., Hernández, F. and Selfa, J. (2009) Comunicación. Primero registro del psilido rojo del eucalipto Glycaspis brimblecombei (Homoptera: Psyllidae), en la Comunidad Valenciana. Boletin Sanidad Vegetal Plagas, 35, 277-281.

[15] Valente, C. and Hodkinson, I. (2009) First record of the red gum lerp psyllid, Glycaspis brimblecombei Moore (Hem.: Psyllidae), in Europe. Journal of Applied Entomology, 133, 315-317. http://dx.doi.org/10.1111/j.1439-0418.2008.01324.x

[16] Laudonia, S. and Garonna, A.P. (2010) The red gum lerp psyllid, Glycaspis brimblecombei, a new exotic pest of Eucalyptus camaldulensis in Italy. Bulletin of Insectology, 63, 233-236.

[17] Halbert, S.E., Gill, R.J. and Nisson, J.N. (2001) Two Eucalyptus psyllids new to Florida (Homoptera: Psyllidae). Florida Department of Agriculture Entomology Circular, 407, 1-2.

[18] Brennan, E.B. and Gill, R. (1999) First record of Glycaspis brimblecombei Moore (Homoptera: Psyllidae) in North America: Initial observations and predator associations of a potentially serious new pest of Eucalyptus in California. Pan-Pacific Entomologist, 75, 55-57. 